\title{
Assessment of Glycemic Responses in Three Traditional Paddy Varieties Conducted by Krishi Vigyan Kendra
}

\author{
S. Kannan*, M. Balarubini and G. Meenalakshmi \\ KVK, Virudhachalam, India \\ *Corresponding author
}

\section{A B S T R A C T}

\section{Keywords}

Rice, Glycemic index and Blood glucose

Article Info

Accepted:

15 February 2019

Available Online:

10 March 2019
Rice is an important staple food for more than half of the world's population. Especially in Asian countries, rice is a major contributor to dietary Glycemic load (GL). Glycemic index (GI) of different varieties of rice (Oryza sativa L.) commonly consumed in are not widely studied even though it is the staple food. To determine the proximate compositions and the GI of three different rice flakes, namely Milled Rice, Mappilai samba rice and Red kavuni rice. The study was a randomised cross over study using healthy Farm women $(n=15)$. GI was determined as the ratio between the incremental areas under curve obtained for the test food and the standard glucose (WHO/FAO method). Proximate compositions were determined by standard methods. Mappilai samba rice and Red kavuni rice (Flakes) are of nutritional significance to individuals seeking to control the energy intake and lower glucose level.

\section{Introduction}

The concept of Glycemic Index (GI) was first developed by Jenkins and colleagues over a quarter of a century ago and has proven to be an important and innovative concept in nutritional science. There is an important body of evidence to support the use and application of low GI diets, not only in the management or prevention of diabetes but also in CVD. In addition, low GI foods have been associated with improved insulin sensitivity and increased colonic fermentation. Glycemic index (GI) is a method of classifying the blood glucose raising potential of carbohydrate rich foods. The GI concept may be of particular benefit in India due to the high prevalence of diabetes and impaired glucose tolerance.

The National Urban Diabetes Survey found that 12 per cent of city-dwelling Indians have type 2 diabetes and 13 per cent of those under 40 years of age have impaired glucose tolerance. Moreover, the prevalence of diabetes in urban India continues to rise. The recent Chennai Urban Rural Epidemiology Study reports that the prevalence of diabetes has reached 14.3 per cent. In particular, Asian Indians are more insulin resistant than other ethnic groups. 
Rice (Oryza sativa L.) is the most important staple food for over half of the world's population (Fairhurst and Dobermann, 2002). Rice is generally considered as high GI food, but has a large variation in GI values ranging as low as 54 to as high as 121 (Atkinson et al., 2008). Moreover, it is known that consumption of white rice is linked with an increased risk for type 2 diabetes ( $\mathrm{Hu}$ et al., 2012).

In light of the above, the study aimed at determining the Glycemic Index (GI) of three different varieties of rice flakes namely Milled Rice flakes, Mappilai samba rice flakes and Red kavuni rice flakes.

\section{Materials and Methods}

The present study an attempt has been conducted as OFT programme during the year 2017-18 by KVK, Virudhachalam. The testing procedure was followed exactly in three groups. Blood samples were taken before and after consumption of flakes. The carbohydrate content of each sample was calculated. For this study three villages were selected namely Sathiyavadi and Elamangalam of vridhachalam block and Gunamangalam of kattumanarkovil block of cuddalore district for each village one self help group were selected to test the blood glucose level for fifteen respondents. The study was a randomised cross over study using healthy Farm women $(n=15)$. Three types of flakes were given to the each person for test the blood glucose level. Tested each flakes once on separate days, with at least $1 \mathrm{~d}$ gap between measurements to minimise carry-over effects. Blood sample was measured by glucose oxidase method using a glucometer and strip (Table 1).

\section{Results and Discussion}

This is the first study known to the authors to examine the role of society on Glycemic Index (GI) when the subjects are resident in their own countries. The importance of society was to establish whether feeding identical foods in two regions of the world would elicit similar or dissimilar Glycemic Index (GI) values. The present study has shown that although the Glycemic response to the flakes was higher in milled rice, there were significant differences in the GI values of the different type of flakes between the three groups. Calculation of Glycemic Index (GI), the absolute blood glucose values for each flakes are noted for each samples. In the study, the people with good health condition were selected for the assessment of glucose level. As shown in Table 2, when the GI values were calculated in each group with different time period in milled type of flakes was tested.

The Table 3 revealed that, when the GI values were calculated in each group with different time period from the person who consumed mapillai samba rice flakes were tested.

Table.1 Performance of the technology

\begin{tabular}{|l|c|c|c|c|}
\hline Technology Option & $\begin{array}{l}\text { No. of } \\
\text { trials }\end{array}$ & $\begin{array}{c}\text { Carbohydrate } \\
\text { content } \\
\text { (gm/100 gm) }\end{array}$ & $\begin{array}{c}\text { Crude } \\
\text { Protein } \\
(\mathbf{g m} / \mathbf{1 0 0} \mathbf{g m})\end{array}$ & $\begin{array}{c}\text { Glycemic } \\
\text { index } \\
(\mathbf{\%})\end{array}$ \\
\hline $\begin{array}{l}\text { TO 1- Milled Rice-BPT } \\
\text { 5220(Existing practice) }\end{array}$ & 3 & 90.10 & 7.25 & 68.50 \\
\hline $\begin{array}{l}\text { TO2- Mapillai Samba Rice } \\
\text { flakes }\end{array}$ & & 85.50 & 11.20 & 55.65 \\
\hline TO3-Red Kavuni rice flakles & & 82.40 & 12.40 & 53.10 \\
\hline
\end{tabular}


Table.2 Farmers practice -milled rice flakes

\begin{tabular}{|c|c|c|c|c|c|c|}
\hline \multirow[t]{2}{*}{$\begin{array}{l}\text { No. of } \\
\text { interventions }\end{array}$} & \multirow{2}{*}{$\begin{array}{l}\text { Carbohydrate } \\
\text { content } \\
(\mathbf{g m} / 100 \mathrm{gm})\end{array}$} & \multirow[t]{2}{*}{$\begin{array}{l}\text { Pre prandial blood } \\
\text { glucose level }(\mathrm{mg} / \mathrm{dl}\end{array}$} & \multicolumn{4}{|c|}{$\begin{array}{l}\text { Post prandial blood glucose level } \\
(\mathrm{mg} / \mathrm{dl})\end{array}$} \\
\hline & & & $\begin{array}{l}30 \\
(\min )\end{array}$ & $\begin{array}{l}60 \\
(\min )\end{array}$ & $\begin{array}{l}90 \\
(\mathrm{~min})\end{array}$ & $\begin{array}{l}120 \\
(\mathrm{~min})\end{array}$ \\
\hline 1 & 90.10 & 110 & 154 & 160 & 156 & 118 \\
\hline 2 & 90.10 & 98 & 140 & 145 & 144 & 105 \\
\hline 3 & 90.10 & 105 & 152 & 158 & 142 & 108 \\
\hline 4 & 90.10 & 118 & 158 & 162 & 154 & 120 \\
\hline 5 & 90.10 & 106 & 153 & 155 & 142 & 116 \\
\hline
\end{tabular}

Table.3 Recommended Practice- Mapillai Samba Rice flakes

\begin{tabular}{|c|c|c|c|c|c|c|}
\hline \multirow[t]{2}{*}{$\begin{array}{c}\text { No. of } \\
\text { interventions }\end{array}$} & \multirow{2}{*}{$\begin{array}{c}\text { Carbohydrate } \\
\text { content } \\
(\mathrm{gm} / 100 \mathrm{gm})\end{array}$} & \multirow[t]{2}{*}{$\begin{array}{l}\text { Pre prandial blood } \\
\text { glucose level }(\mathrm{mg} / \mathrm{dl}\end{array}$} & \multicolumn{4}{|c|}{$\begin{array}{l}\text { Post prandial blood glucose level } \\
(\mathrm{mg} / \mathrm{dl})\end{array}$} \\
\hline & & & $\begin{array}{c}30 \\
(\mathrm{~min})\end{array}$ & $\begin{array}{c}60 \\
(\min )\end{array}$ & $\begin{array}{c}90 \\
(\mathrm{~min})\end{array}$ & $\begin{array}{c}120 \\
(\min )\end{array}$ \\
\hline 1 & 85.50 & 115 & 128 & 139 & 135 & 112 \\
\hline 2 & 85.50 & 108 & 124 & 136 & 131 & 105 \\
\hline 3 & 85.50 & 106 & 121 & 140 & 139 & 102 \\
\hline 4 & 85.50 & 116 & 134 & 152 & 147 & 111 \\
\hline 5 & 85.50 & 108 & 123 & 145 & 141 & 101 \\
\hline
\end{tabular}

Table.4 Recommended practice- red Kavuni rice flakes

\begin{tabular}{|c|c|c|c|c|c|c|}
\hline $\begin{array}{c}\text { No. of } \\
\text { interventions }\end{array}$ & $\begin{array}{c}\text { Carbohydrate } \\
(\mathbf{g m})\end{array}$ & \multicolumn{2}{|c|}{$\begin{array}{c}\text { Pre prandial blood } \\
\text { glucose level (mg/dl) }\end{array}$} & \multicolumn{4}{|c|}{ Post prandial blood glucose level } \\
& & & & \multicolumn{3}{|c|}{ (mg/dl) } \\
& & & 30 & 60 & 90 & 120 \\
$(\mathrm{~min})$ & $(\mathrm{min})$ & $(\mathrm{min})$ & $(\mathrm{min})$ \\
\hline $\mathbf{1}$ & 82.40 & 112 & 124 & 140 & 138 & 110 \\
\hline $\mathbf{2}$ & 82.40 & 110 & 123 & 153 & 148 & 106 \\
\hline $\mathbf{3}$ & 82.40 & 102 & 114 & 149 & 144 & 101 \\
\hline $\mathbf{4}$ & 82.40 & 104 & 127 & 151 & 147 & 102 \\
\hline $\mathbf{5}$ & 82.40 & 111 & 125 & 149 & 145 & 110 \\
\hline
\end{tabular}

The Table 4 expressed that, when the GI values were calculated from the person who consumed Red kavuni rice flakes were tested. The result of the studies shows that the lower glucose level were observed from the person who consumed Red kavuni rice flakes and followed by Mappilai samba rice flakes. The reduction of glucose was observed from the technology option when compared to the existing practices.

In conclusion, while rice as a total category may be a major global contributor to dietary Glycemic load, there is a wide variation in blood glucose responses to rice flakes as consumed. Red kavuni rice flakes is good 
when compared to milled rice flakes. Technology option gives much better result when compared to existing practices. The flavor and taste of rice flakes are good. Colour of rice flakes is appealing lower blood glucose level is observed among the beneficiary. The performance of traditional paddy varieties is excellent when compared with ordinary milled rice flakes. Slow release of glucose level in blood because the fibre content is more in traditional rice flakes.

\section{References}

Atkinson, F.S., Foster-Powell, K. and BrandMiller, J.C. 2008. International tables of glycemic index and glycemic load values. Diabetes Care 31: 2281-2283.

Fairhurst, T.H. and Dobermann, A. 2002. Rice in the global food supply. Better Crops International 16: 3-6.

FAO/WHO. 1998. Carbohydrates in Human Nutrition. Report of a Joint FAO/WHO Expert Consultation. Rome: Food and Agriculture Organization/World Health Organization.

$\mathrm{Hu}$, E.A., Pan, A., Malik, V. and Sun, Q. 2012. White rice consumption and risk of type 2 diabetes: meta-analysis and systematic review. British Medical Journal 344:e1454.

\section{How to cite this article:}

Kannan, S., M. Balarubini and Meenalakshmi, G. 2019. Assessment of Glycemic Responses in Three Traditional Paddy Varieties Conducted by Krishi Vigyan Kendra. Int.J.Curr.Microbiol.App.Sci. 8(03): 1736-1739. doi: https://doi.org/10.20546/ijcmas.2019.803.202 